\title{
Cavitation as a Potential Technology for Wastewater Management - An Example of Enhanced Nutrient Release from Secondary Pulp and Paper Mill Sludge
}

\author{
Mija Sežun ${ }^{1}$ - Janez Kosel ${ }^{2}$ - Mojca Zupanc ${ }^{3}$ - Marko Hočevar ${ }^{3}-$ \\ Janez Vrtovšek ${ }^{3}$ - Martin Petkovšek ${ }^{3}$ - Matevž Dular3,* \\ 1Pulp and Paper Institute, Slovenia \\ 2Institute for the Protection of Cultural Heritage of Slovenia, Slovenia \\ 3University of Ljubljana, Faculty of Mechanical Engineering, Slovenia
}

Wastewater recycling and sludge removal in the paper industry account for about $60 \%$ of all process costs. New and environmentally friendly wastewater treatment techniques are, therefore, continually being developed. Cavitation exploitation is currently a well-investigated topic that is also interesting for the paper production industry. This study investigates efficiency of hydrodynamic cavitation alone and in combination with the addition of $\mathrm{NaOH}$ for the treatment of secondary pulp and paper mill sludge in order to enhance nutrient release. First, two laboratoryscale devices were tested: the blow-through and the rotating hydrodynamic cavitation generator. The latter set-up proved to be more efficient: therefore, further experiments were performed on its pilot-scale version. The results showed an increase of soluble chemical oxygen demand $\left(\mathrm{COD}_{\mathrm{s}}\right)$ by $514 \mathrm{mg} / \mathrm{L}$, total nitrogen $\left(\mathrm{N}_{t}\right)$ by $17.4 \mathrm{mg} / \mathrm{L}$, and total phosphorous $\left(P_{t}\right)$ by $2.3 \mathrm{mg} / \mathrm{L}$. To further increase nutrient release combination of cavitation and sludge sample alkalinization was tested. The addition of $\mathrm{NaOH}$ and $30 \mathrm{~min}$ cavitation of secondary sludge (500 L) significantly improved $\mathrm{COD}_{\mathrm{s}}$ and $\mathrm{N}_{\mathrm{t}}$ release by $2400 \mathrm{mg} / \mathrm{L}$ and $120 \mathrm{mg} / \mathrm{L}$, respectively. Microbiological photos revealed a definite disintegration of sludge flocks. According to our estimates, $1.9 \mathrm{~kg}$ of released $\mathrm{COD}_{\mathrm{s}}$ from alkaline pre-treated and cavitated sludge would cost only one euro.

Keywords: hydrodynamic cavitation, nutrients, paper mill plant, secondary sludge, sludge disintegration, wastewater treatment

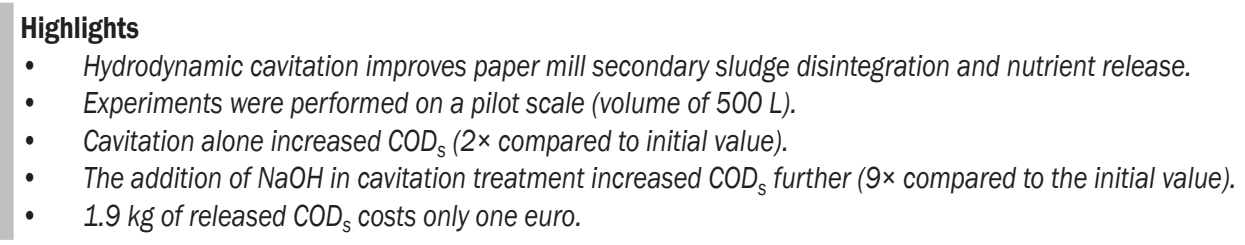

\section{INTRODUCTION}

Cavitation can be described as the appearance of vapour bubbles (cavities) inside a liquid medium. The phenomenon is similar to boiling, but in contrast, is initiated by the sudden decrease in pressure while the temperature remains approximately constant. As the pressure recovers, the bubble goes through a violent collapse. If the bubble collapses spherically, pressure shocks up to several $100 \mathrm{MPa}$ [1] can be emitted. In contrast, with an asymmetrical collapse, so-called microjets with high velocities above $100 \mathrm{~m} / \mathrm{s}$ can form [2]. In addition, so-called hot spots with extreme temperatures in the order of several $1000 \mathrm{~K}$ [3] can form at the centre of the bubble at its collapse, which can cause the formation of highly reactive radicals such as $\mathrm{OH}[4]$.

In general, two types of cavitation are recognized: hydrodynamic (HC) and acoustic cavitation (AC). The difference is in the mechanism, which causes the local pressure to drop, while the principles that govern the hydrodynamically and acoustically generated bubbles are basically the same. In the case of HC, acceleration of the liquid flow causes local pressure drop, which can, if the pressure drops below saturated pressure, trigger the cavitation formation. Depending on the flow conditions, the size of the formed cavitation bubbles varies, usually between a few $\mathrm{nm}$ to a few $\mathrm{mm}$. Flow conditions and the geometry of the submerged body define cavitation behaviour and its characteristics. HC can be in general divided into i) attached cavitation, ii) developed cloud shedding cavitation, and iii) supercavitation. In the case of attached cavitation, a large number of vapor bubbles are attached to the surface of the constriction, forming an attached cloud-like shape. If we further increase the flow velocity or decrease the static pressure in the system, the previously attached cavitation cloud becomes unstable and starts (partly or completely) to shed from the main cavitation structure; this stage is called developed or cloud shedding cavitation. This condition is also known as the most aggressive one. With further increases of the flow velocity (or decrease of system pressure), the so-called supercavitation 
forms. It starts when the individual bubbles coalesce and eventually form a single, large, and stable vapor pocket.

Cavitation is usually associated with engineering problems, such as material loss, noise, vibration, and the decreased of efficiency of hydraulic machines. However, cavitation is a potentially useful phenomenon: the extreme conditions are increasingly used for a wide variety of applications, such as surface cleaning, enhanced chemistry, and wastewater treatment (bacteria eradication and virus inactivation).

Nowadays, the availability of clean water is becoming an increasing concern in the globalized world, in both developed and developing countries. Therefore, an efficient and clean wastewater cleaning and disinfection technology, such as cavitation, would be readily welcome to substitute or be combined with the existing ones.

The regulations regarding waste management have become stricter and, in order to satisfy set environmental limits, many industries must implement their own wastewater treatment facilities. One such industry is the paper production industry. For paper production, $54 \%$ of materials are raw, and the rest are sourced from recovered paper and board. Therefore, paper is the most recycled product in Europe, and Europe is the global leader in paper recycling, with a recycling rate of $72 \%$ [5]. Globally, the pulp and paper industry is currently on the rise, and, subsequently, an enormous amount of waste is generated every day. The most common waste material generated in pulp and paper mills is ash, dregs, grits, pulp mill sludge, and a significant amount of wastewater depending on the type of processes used in the plant. In the past, these wastes were simply deposited on the landfills; however, with changes in regulation and with increased environmental awareness, new alternatives have been investigated, especially reappraising these materials as valuable [6]. Due to the numerous impurities, health hazards, and environmental risks present in wastewater, an effective cleaning measure has to be implemented [7]. Accordingly, in the pulp and paper industry, several wastewater treatment systems exist for the removal of organic and inorganic substances in order to meet the effluent discharge standards. These include anaerobic treatments, activated sludge lagoons, and clarifier systems. Established wastewater recycling and sludge removal are, therefore, very expensive, amounting to as much as $60 \%$ of all process costs [8]; consequently, new and alternative solutions are being developed.

Numerous studies have been made to reduce energy consumption, to produce new materials and products and to reuse or circulate the sludge [9], for example, anaerobic digestion [10] and [11] for the formation of biogas and for the production of biohydrogen [12] and [13], addition into building materials [14] and [15], and for the production of activated carbon [16].

One ever more commonly applied mechanical pre-treatment alternative is cavitation. It can be used alone or in combination with various treatments. During the cavitation process, extreme conditions can occur, forming highly intensive shockwaves, microjets, and extreme temperatures, which can drive mechanical and chemical effects. Shear forces released and production of $\cdot \mathrm{OH}$ by decomposition of water molecules [4] can both influence sludge disintegration [17] and [18]. AC alone and coupled with chemical treatment has been thoroughly investigated for the disintegration of different waste sludges before aerobic processes for nutrient reuse [17], [19], and [20] and anaerobic processes for biogas production [21] to [23].

\subsection{Contributions of Our Research Group on the Topic of HC Use in Wastewater Treatment}

Since 2012, our research group has been engaged in the development of efficient cavitation-based technologies for wastewater treatment and sludge remediation, mainly for the removal of chemical and microbiological pollutants.

Our initial focus was on the removal of persistent pharmaceuticals, such as ibuprofen, ketoprofen, diclofenac, naproxen, carbamazepine, and clofibric acid [24] and [25]; we applied $\mathrm{HC}$ for wasteactivated sludge disintegration [23]. Concurrently, we developed several cavitation reactors [26] and filed several national [27] and international [28] patents. The shift from applied towards basic research came with studies of cavitation influence on bacteria Legionella pneumophila [29]. In our next study, it was demonstrated that the least aggressive cavitation type (supercavitation) hydrodynamically is the most destructive against the bacteria [30]. We questioned several well-established postulates [31] and [32]. By gaining new knowledge, we again progressed in applied science and for the first time showed that cavitation can be exploited for virus inactivation [33], and even for "exotic" applications, such as intensification of aqueous laundry detergent solution preparation [34].

In 2018, we were awarded a European Research Council (ERC) project CABUM, with which we aim, during the course of five years, to 
gain a deeper understanding of the mechanisms [35] that will eventually enable reliable cavitation exploitation in various disciplines. Recently, we have also investigated the application of cavitation in the paper production industry. We have shown that cavitation can be used to replace processes such as homogenization, fibrillation, and refining of paper pulp [36].

We have continued with the investigations of applicability of cavitation in paper producing plants. The main objective and innovation of this study were thus to determine the effectiveness of a hydrodynamic cavitation set-up for the treatment of paper mill secondary sludge. By implementing cavitation, our objective was to achieve a greater nutrient release and greater disintegration of biological compounds. Different cavitation set-ups, the addition of $\mathrm{NaOH}$ to sludge samples, as well as different treatment times were tested. The first experiments were conducted in the laboratory, and pilot scale experiments followed.

\section{MATERIALS AND METHODS}

\subsection{Sample Characterization}

Total chemical oxygen demand $\left(\mathrm{COD}_{t}\right)$ and soluble $\mathrm{COD}\left(\mathrm{COD}_{s}\right)$ were measured using COD cuvette tests (Hach Lange LCK 314 for samples with a COD value between $15 \mathrm{mg} \mathrm{O}_{2} / \mathrm{L}$ and $150 \mathrm{mg} \mathrm{O}_{2} / \mathrm{L}$ and LCK 714 for samples with a COD value between 100 $\mathrm{mg} \mathrm{O}_{2} / \mathrm{L}$ and $600 \mathrm{mg} \mathrm{O}_{2} / \mathrm{L}$ ). Total nitrogen $\left(\mathrm{N}_{t}\right)$ was determined by using $\mathrm{N}_{t}$ cuvette tests (Hach Lange LCK 138 for samples with values of $\mathrm{N}_{t}$ between $1 \mathrm{mg} /$ $\mathrm{L} / \mathrm{L}$ and $16 \mathrm{mg} / \mathrm{L} / \mathrm{L}$ and LCK 338 for samples with $\mathrm{N}_{t}$ values between $20 \mathrm{mg} / \mathrm{L} / \mathrm{L}$ and $100 \mathrm{mg} / \mathrm{L}$ ). Total phosphorous $\left(\mathrm{P}_{t}\right)$ was measured using the PhosVer 3 (Ascorbic Acid) method (\#8048, Hach Lange). For these measurements, a DR3900 spectrophotometer (Hach-Lange, Germany) was used. $\mathrm{pH}$ value and redox potential were determined during sampling on site, with a Multi 340i analyser (WTW, Germany). Settleable solids were analysed according to the Deutsches Institut fur Normung (DIN 38409-2, 1980) [37], in which settleable substances were shaken, and timed sedimentation was determined in a measuring container. The calorific value was determined using ASTM methods [38].

\subsection{Hydrodynamic Cavitation Set-ups}

The effects of HC on pulp and paper mill secondary sludge were investigated on lab-scale and pilot-scale cavitation devices. For lab-scale experiments, the effects of two different HC set-ups were investigated. Firstly, the blow-through hydrodynamic cavitation (BTHC) set-up using a symmetrical Venturi constriction was tested. Second, the rotating generator of hydrodynamic cavitation (RGHC) was tested. The lab-scale experiments were performed on $1 \mathrm{~L}$ samples for 30 minutes, below $30{ }^{\circ} \mathrm{C}$. While the BTHC device was designed only for lab-scale experiments, the RGHC was additionally scaled up to perform pilot experiments. The pilot-scale experiments were performed on $500 \mathrm{~L}$ samples for $30 \mathrm{~min}$, below 30 ${ }^{\circ} \mathrm{C}$. All cavitation devices used in this paper were developed and designed by Laboratory for Hydraulic Machines, Department of Power Engineering, Faculty of the Mechanical Engineering, University of Ljubljana, Slovenia.

\subsubsection{Blow-Through Hydrodynamic Cavitation Set-up (BTHC)}

The lab-scale reactor for cavitation generation, BTHC (Fig. 1), consists of two reservoirs connected by a symmetrical Venturi constriction. $1 \mathrm{~L}$ of sample is introduced into the right reservoir (state 1, Fig. 1) and pushed through the Venturi constriction, where cavitation occurs, into the left reservoir using compressed air (state 2, Fig. 1). After the whole sample is pushed into the left reservoir (state 3, Fig. 1 ), the procedure is repeated, and the sample is pushed back to the right reservoir (state 4, Fig. 1). The time needed to push $1 \mathrm{~L}$ of the sample from one reservoir to another is 6 seconds at 7 bar pressure difference. The BTHC set-up is in more detail described in [24].

\subsubsection{Rotating Hydrodynamic Cavitation Generator (RGHC) Set-up}

The lab-scale device (Fig. 1) consists of a reservoir, RGHC, and a heat exchanger. The sample introduced into the reservoir flows through the RGHC, where it is exposed to cavitation and through the heat exchanger, which provides the constant temperature of the sample, back into the reservoir. The heat exchanger (water to air) is force-cooled by an external fan. RGHC is based on a rotor-stator design, in which the rotor and stator have specially designed geometry, which causes periodically repeating pressure oscillations. With the pressure oscillations, the cavitation periodically forms in the gap between rotor-stator, on the rotor's teeth and in the rotor's and stator's grooves. The rotor with 50 $\mathrm{mm}$ in diameter is driven by a $400 \mathrm{~W}$ electrical motor at approx. $10.000 \mathrm{rpm}$. The RGHC is in presented more detail in [39]. 
a)
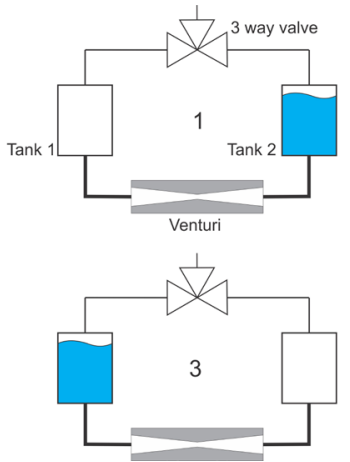
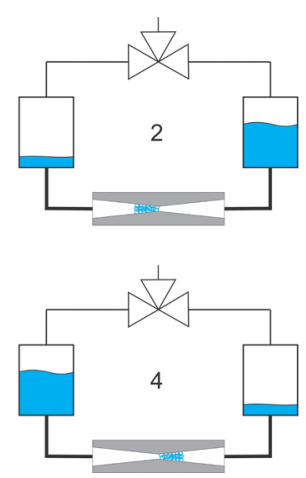

b)

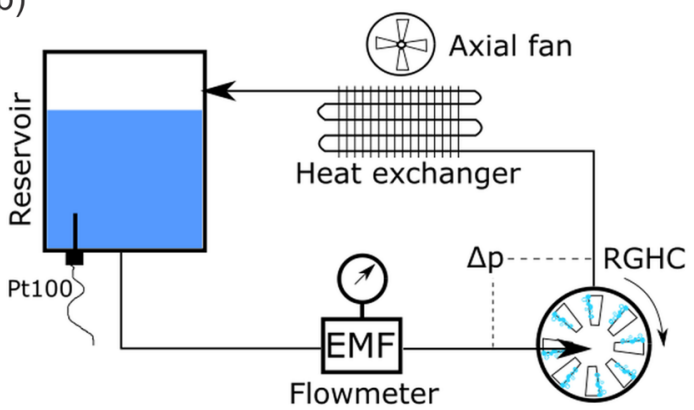

Fig. 1. a) Schematic presentation of BTHC [24], and b) schematic presentation of lab-scale RGHC experimental set-up

The pilot-scale RGHC design is similar to the lab-scale and is described in more detail in [23]. The main differences are that the pilot-scale RGHC does not have a heat exchanger, has a rotor with $190 \mathrm{~mm}$ in diameter and is driven by a $5.5 \mathrm{~kW}$ electric motor at $2800 \mathrm{rpm}$. In the pilot-scale device, larger samples can be treated, in our case $500 \mathrm{~L}$.

\section{RESULTS AND DISCUSSION}

\subsection{Lab-scale Experiments}

The effect of the hydrodynamic cavitation generated inside the laboratory scaled RGHC and BTHC devices on the composition of pulp and paper mill secondary sludge is presented in Fig. 2. In these experiments, the samples were exposed to cavitation for $30 \mathrm{~min}$; after treatment $\mathrm{N}_{t}, \mathrm{COD} t$ and $\mathrm{COD}_{s}$ were measured.

Based on the results, we can see that both cavitation devices significantly decreased the $\mathrm{COD}_{t}$ the value of the secondary pulp and paper mill sludge. We suspect that this was due to the mineralization of compounds, i.e., the degradation/oxidation of compounds in organic matter and the release of simple nutrients [40]. We can also see that $\mathrm{COD}_{s}$ and $\mathrm{N}_{t}$ increased in both cavitation devices. That is probably because extreme conditions during cavitation ruptured the membranes of microorganisms and released their intercellular contents into the bulk solution [23]. These released compounds, which are, together with wastewater, returned to the biological wastewater treatment process can replace a part of the outside nutrient source, which are necessary for a stable operation of the pulp and paper mill wastewater plant. Additionally, with the destruction of microorganisms, the amount of sediment decreases, which has beneficial effects on the final treatment of pulp and paper mill sludge.

In the case of the RGHC, the increase of $\mathrm{N}_{t}$ and $\mathrm{COD}_{s}$ is higher than for the BTHC device, which indicates its higher efficiency at approximately the same energy input per litre of the sample (Fig. 2). The reason for its greater $\mathrm{COD}_{s}$ and $\mathrm{N}_{t}$ release may be in the fact that the sample was subjected to more intensive shear flow conditions during this type of cavitation [30]. In the RGHC device, the rotor's and stator's teeth are periodically interacting with each other, resulting in intense pressure fluctuations. Each rotor-stator teeth pair (with a $1 \mathrm{~mm}$ gap between opposite teeth) forms a quasi-Venturi constriction,

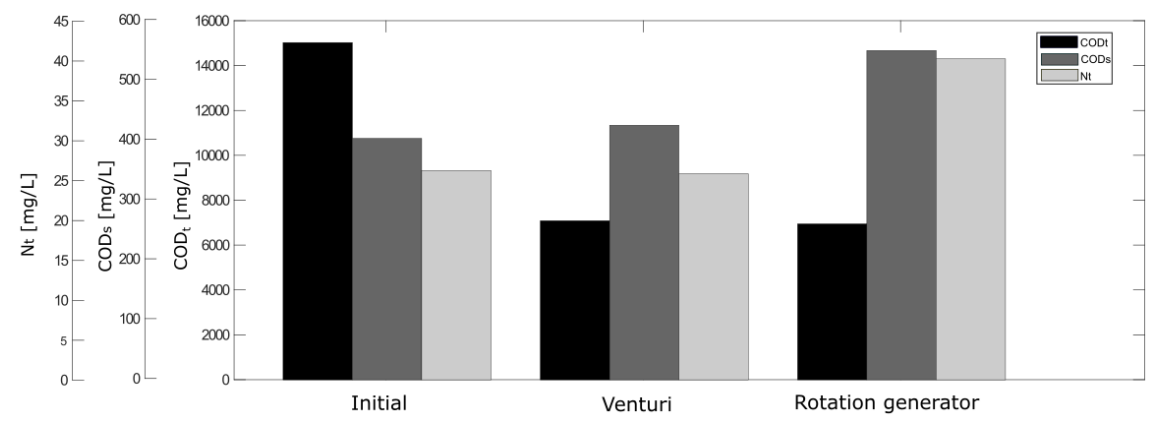

Fig. 2. $N_{t}, C O D_{t}$ and CODs measurements before and after treatment with two types of cavitation devices (BTHC and RGHC) on lab-Scale 
which might explain the higher efficiency of RGHC with a high number of constrictions, compared to only one in BTHC [30].

In addition to the laboratory-scale experiments with the RGHC device, which resulted in the highly positive effect of $\mathrm{HC}$ towards mineralization, additional experiments of the sole effect of alkalinization (addition of $\mathrm{NaOH}$ until the $\mathrm{pH}$ value was 10) on the chemical composition of secondary pulp and paper mill sludge were also performed. These tests were conducted in $1 \mathrm{~L}$ jars which were stirred for $30 \mathrm{~min}$ by a magnetic stirrer.

The results showed that alkalinization alone increased the $\mathrm{COD}_{s}$ value from $315 \mathrm{mg} / \mathrm{L}$ to 990 $\mathrm{mg} / \mathrm{L}$. Therefore, we decided to evaluate the possible synergistic effect of cavitating alkaline pre-treated secondary pulp and paper mill sludge (pH value of 10) in the pilot-scale RGHC device.

\subsection{Pilot-scale Experiments}

In Table 1, the effect of $\mathrm{HC}$ generated inside the pilotscale RGHC device on the chemical characteristics of the secondary pulp and paper mill sludge is presented. After 30 min of cavitation, the $\mathrm{COD}_{s}$ value increased by $514 \mathrm{mg} / \mathrm{L}$. Apart from the $\mathrm{N}_{t}(17.4 \mathrm{mg} / \mathrm{L})$, the cavitation treatment generated inside the pilot- scale RGHC also increased the total phosphorous released $\left(\mathrm{P}_{t}\right)$ from $0.6 \mathrm{mg} / \mathrm{L}$ to $2.9 \mathrm{mg} / \mathrm{L}$. Therefore, as stated previously, cavitation increases the release of valuable nutrients making them available for future applications. Moreover, cavitation in the scaled-up cavitator decreased the calorific value of dry mass as well as the amount of settleable solids. Decreasing the weight of dry matter can have positive effects on lower transportation, deposition and incineration costs.

Fig. 3 shows the $\mathrm{COD}_{s}$ and $\mathrm{N}_{t}$ values before and after cavitation treatment $(15 \mathrm{~min}$ and $30 \mathrm{~min})$ of secondary pulp and paper mill sludge and alkaline treated secondary pulp and paper mill sludge $(\mathrm{pH}$ 10) using the pilot-scale RGHC device. The obtained results clearly show a parallel increase of the $\mathrm{COD}_{s}$ and $\mathrm{N}_{t}$ values with the cavitation treatment time and additionally confirm that the addition of $\mathrm{NaOH}$ intensively boosts the disintegration process. In an alkaline environment, autoxidation [41] and a minimum degradation of proteins, which are released from ruptured microrganisms, takes place producing various oxidized radicals [42] and cysteine, methionine, tryptophan, histidine, and tyrosine residues are especially susceptive to oxidative destruction whereas asparagine and aspartic acid undergo deamination [43]. In zones of $\mathrm{HC}$ development, high pressures and

Table 1. Effect of HC generated inside the pilot-scale RGHC device (30 min) on the chemical characteristics of the secondary pulp and paper mill sludge

\begin{tabular}{lccccc}
\hline & $\begin{array}{c}\mathrm{P}_{t} \\
{[\mathrm{mg} / \mathrm{L}]}\end{array}$ & $\begin{array}{c}\mathrm{N}_{t} \\
{[\mathrm{mg} / \mathrm{L}]}\end{array}$ & $\begin{array}{c}\mathrm{COD}_{s} \\
{[\mathrm{mg} / \mathrm{L}]}\end{array}$ & $\begin{array}{c}\text { Calorific value of dry mass } \\
{[\mathrm{kJ} / \mathrm{kg} \text { dry mass }]}\end{array}$ & $\begin{array}{c}\text { Settleable solids } \\
{[\%]}\end{array}$ \\
\hline Secondary pulp and paper mill sludge & 0.6 & 8.1 & 509 & 18097 & 18.5 \\
\hline Cavitated secondary pulp and paper mill sludge & 2.9 & 25.5 & 1023 & 17793 & 16.5 \\
\hline
\end{tabular}

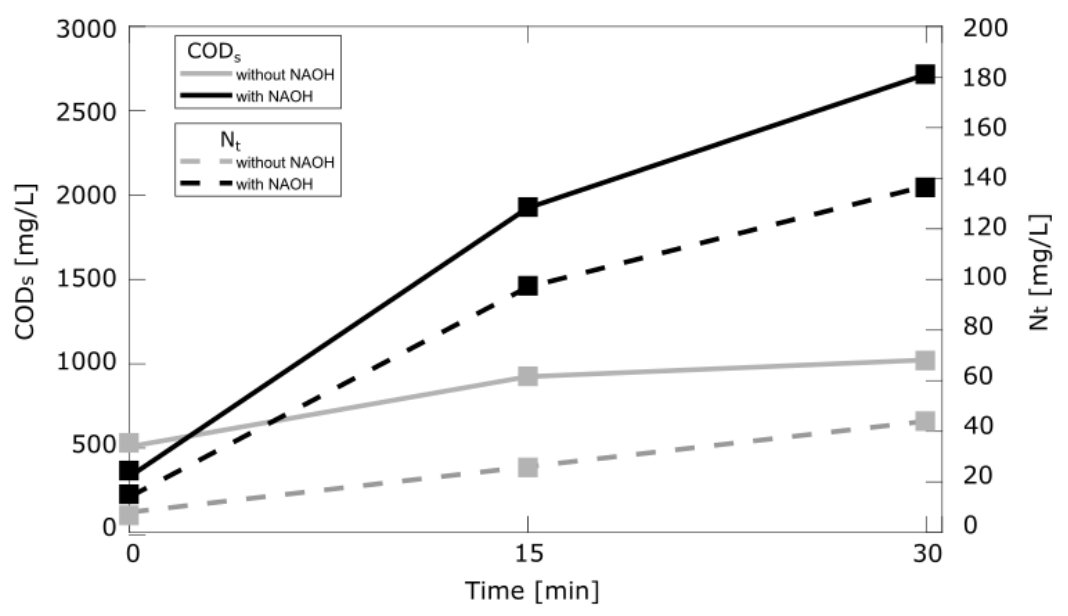

Fig. 3. The effect of secondary pulp and paper mill sludge alkalinization ( $\mathrm{pH}$ of 10) on the $\mathrm{N}_{t}$ and $\mathrm{COD}_{\mathrm{s}}$ measurements before and after cavitation in the pilot-scale RGHC device 
temperatures cause water molecules to dissociate into hydroxyl radicals $\left({ }^{\circ} \mathrm{OH}\right)$ and $\cdot \mathrm{H}[44]$. When cavitation takes place in an alkaline environment, a further recombination reaction between these radicals can lead to the formation of peroxide $\left(\mathrm{H}_{2} \mathrm{O}_{2}\right)$, hydroperoxy radicals ( $\mathrm{HOO} \cdot)$ and superoxide anions $\left({ }^{\circ} \mathrm{O}^{-2}\right)$. Oxidized radicals derived from proteins then undergo reactions with the $\cdot \mathrm{OH}, \cdot \mathrm{OOH}$ and ${ }^{\cdot} \mathrm{O}^{-2}$ radicals to form simple organic acids, carbon dioxide and other low molecular weight organic products [45] and [41]. Therefore, in theory, alkaline pre-treatment initializes the protein degradation process, and $\mathrm{HC}$ provides additional oxidative potential, which is required for the intensification and acceleration of reactions and consequently for the increased release of nutrients from biomass (such as nitrogen and phosphorous).

The assumption of microbial rupture during cavitation with secondary pulp and paper mill sludge was confirmed by microbiological photos and microbial counts under the microscope (40 and 100 times magnified). These were taken before and after the pilot-scale RGHC experiments with secondary pulp and paper mill sludge, which are described above (Fig. 3).

From the microscope photos (Fig. 4 frame A40), it can be clearly seen that non-cavitated secondary pulp and paper mill sludge is made of many solid irregularly shaped flocs of microorganisms which range from $100 \mathrm{~mm}$ to $400 \mathrm{~mm}$ in diameter. At higher magnitude (Fig. 4, frame A100), one can see that the flocs are mainly composed of a mixture of bacteria, primarily Zoogloea and the filamentous bacteria. Zoogloea plays an important role in wastewater treatment because it is capable of lowering BOD5. It also creates habitats for secondary sludge flocs [46]. In contrast, excessive growth of filamentous bacteria in secondary sludge causes poor settlement of secondary sludge flocs, creating a severe operational problem in wastewater treatment systems that is referred to as bulking [47]. After a 30 min cavitation treatment (Fig. 4 frames B40 and B100), the big flocs have been almost completely broken, and the surviving microorganisms are equally dispersed across the whole volume, which indicates a better microbial disintegration.

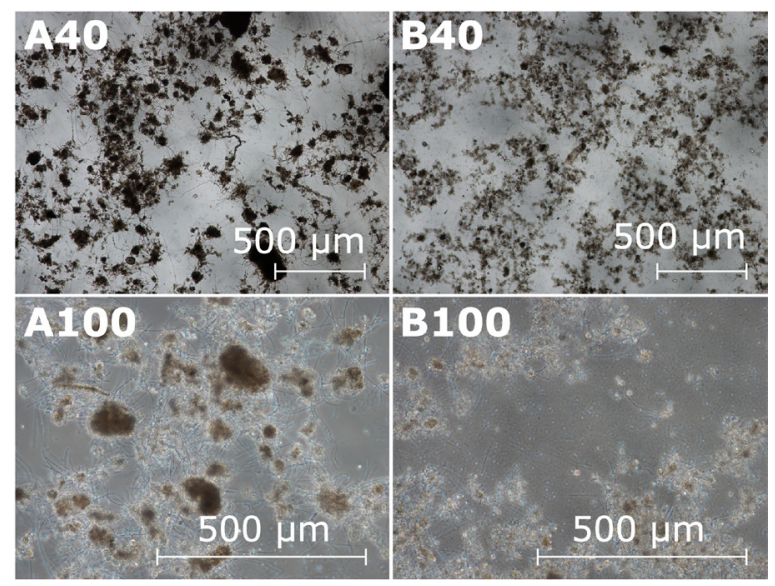

Fig. 4. Microbiological photographs ( $A 40$ and $A 100$ : non-treated secondary pulp and paper mill sludge; B40 and B100: secondary pulp and paper mill sludge after 30 min of treatment using the pilot-scale RGHC device)

Flocculated aggregates are usually colonized by numerous protozoans, which graze on bacteria and the extracellular polymeric substances of the bacteria, and affect the floc size, shape and its functional characteristics [48] to [50].

\subsubsection{Estimation of Energy Efficiency in Waste Water Samples}

Energy $(\mathrm{EnE}(\mathrm{mg} /(\mathrm{Wh})))$ and economic efficiency $(\operatorname{EcE}(\mathrm{mg} / €))$ were estimated for pilot-scale experiments, where $\mathrm{HC}$ alone, $\mathrm{HC}$ with the addition of $\mathrm{NaOH}$ and only $\mathrm{NaOH}$ treatment of secondary paper mill sludge were investigated. Calculations are based on the energy consumption (EC) needed to drive the pilot RGHC, on the increase in soluble COD $\left(\mathrm{DCOD}_{s}\right)$ and on the addition of $\mathrm{NaOH}$ and were evaluated in

Table 2. Energy and economic efficiency of different treatments

\begin{tabular}{lcccccc}
\hline & $\begin{array}{c}\mathrm{t} \\
{[\mathrm{min}]}\end{array}$ & $\begin{array}{c}\Delta \mathrm{COD} \\
{[\mathrm{mg} / \mathrm{L}]}\end{array}$ & $\begin{array}{c}\mathrm{EC} \\
{[\mathrm{Wh}]}\end{array}$ & $\begin{array}{c}\mathrm{cost} / \mathrm{V} \\
{\left[€ / \mathrm{m}^{3}\right]}\end{array}$ & $\begin{array}{c}\mathrm{EnE} \\
{[\mathrm{mg} /(\mathrm{Wh})]}\end{array}$ & $\begin{array}{c}\mathrm{EcE} \\
{[\mathrm{kg} / \mathrm{\epsilon}]}\end{array}$ \\
\hline \multirow{2}{*}{ Hydrodynamic cavitation } & 15 & 415 & 1955 & 0.339 & 106 & 1.224 \\
\hline \multirow{2}{*}{ Hydrodynamic cavitation $+\mathrm{NaOH}(\mathrm{pH}$ of 10) } & 30 & 514 & 3913 & 0.678 & 66 & 0.758 \\
\hline \multirow{2}{*}{$\mathrm{NaOH}^{*}$} & 15 & 1594 & 2000 & $0.346+0.5$ & 399 & 1.884 \\
\cline { 2 - 7 } & 30 & 2386 & 3925 & $0.80+0.5$ & 304 & 1.835 \\
\cline { 2 - 7 } & 8.9 & 40 & $/$ & 0.5 & $/$ & 0.080 \\
\hline
\end{tabular}

*stirred for 30 min on magnetic stirrer 
euro $(€)$ per volume. For each experiment, the EC of the pilot-scale RGHC device was precisely measured with Fluke Norma 4000 power analyser. Higher EnE values correspond to higher treatment efficiencies.

According to the Eurostat [51] statistics, one kWh is on average worth $€ 0.0866$ and $1 \mathrm{~L}$ of Slovenian purchased $\mathrm{NaOH}$ is worth approximately $€ 1.00$. These values were considered for the calculations in Table 2.

From Table 2, it can clearly be seen that in terms of EC and cost efficiency the most promising procedure is comprised of a $15 \mathrm{~min} \mathrm{HC}$ treatment of alkaline treated secondary pulp and paper mill sludge, for which the cost of $1.9 \mathrm{~kg}$ of released $\mathrm{COD}_{s}$ was only $€ 1.00$.

\section{CONCLUSIONS}

In this study, we investigated the effects of different HC treatments on secondary pulp and paper mill sludge, which originated from the local paper mill plant. The experiments were performed on lab- and pilot-scale. The results were evaluated in terms of chemical and microbiological characterization. In addition, energy and economic feasibility calculations were performed.

It can be seen from the presented results that $\mathrm{HC}$ has many beneficial effects on pulp and paper mill secondary sludge disintegration, which leads to improved nutrient release. Moreover, the alkalinization of sludge ( $\mathrm{pH} 10)$ prior to cavitation, additionally improved the economic efficiency of the pilot scale RGHC device. An additional beneficial effect of sludge disintegration is in a decreased weight of dry matter, which is directly reflected in lower transportation, deposition and incineration costs. All these effects can improve wastewater management and reduce operational costs for the paper mill plant. The most effective pilot-scale treatment resulted in 1.9 $\mathrm{kg}$ of released $\mathrm{COD}_{s}$ for which the cost was only 1.00 $€$. Based on the presented results, cavitation seems a promising technique that could be used for various paper mill plant sections.

\section{ACKNOWLEDGEMENTS}

The authors would like to thank the European Commission for funding the InnoRenew CoE project under the Horizon2020 Widespread-Teaming program (grant agreement ID: 739574); Slovenia's Smart Specialization Strategy for funding the Research, development and innovation project (RDI) Cel.Cycle (contract number: OP20.00365) and the Slovenian Research Agency for funding under the scope of project Z2-8188 core research program P2-0401. We thank the paper company Vipap Videm Krško for their cooperation and support.

\section{REFERENCES}

[1] Wang, Y., Brennen, C.E. (1994). Shock wave development in the collapse of a cloud of bubbles. American Society of Mechanical Engineers, Fluids Engineering Division (Publication) FED, vol. 194, p. 15-19.

[2] Franc, J.P., Michel, J.M. (2004). Fundamentals of Cavitation, Kluwer Academic Publishers, Dordrecht.

[3] Fujikawa, S., Akamatsu, T. (1980). Effects of the nonequilibrium condensation of vapour on the pressure wave produced by the collapse of a bubble in a liquid. Journal of Fluid Mechanics, vol. 97, no. 3, p. 481-512, Dol:10.1017/ S0022112080002662.

[4] Braeutigam, P., Franke, M., Schneider, R.J., Lehmann, A., Stolle, A., Ondruschka, B. (2012). Degradation of carbamazepine in environmentally relevant concentrations in water by Hydrodynamic-Acoustic-Cavitation (HAC). Water Research, vol. 46, no. 7, p. 2469-2477, D0l:10.1016/j. watres.2012.02.013.

[5] Confederation of EU Paper Industries (2018). EU's new circular bioeconomy strategy - European forest fibre and paper industry ready to lead, from http://www.cepi.org/EU_ bioeconomy_strategy, accessed on 2019-09-10.

[6] Simão, L., Hotza, D., Raupp-Pereira, F., Labrincha, J.A., Montedo, O.R.K. (2018). Wastes from pulp and paper mills - a review of generation and recycling alternatives. Ceramica, vol. 64, no. 371, p. 443-453, Dol:10.1590/036669132018643712414.

[7] Ashrafi, O., Yerushalmi, L., Haghighat, F. (2015). Wastewater treatment in the pulp-and-paper industry: A review of treatment processes and the associated greenhouse gas emission. Journal of Environmental Management, vol. 158, p. 146-157, D0I:10.1016/j.jenvman.2015.05.010.

[8] Mahmood, T., Elliott, A. (2006). A review of secondary sludge reduction technologies for the pulp and paper industry. Water Research, vol. 40, no. 11, p. 2093-2112, Dol:10.1016/j. watres.2006.04.001.

[9] Bousios, S., Worrell, E. (2017). Towards a Multiple InputMultiple Output paper mill: Opportunities for alternative raw materials and sidestream valorisation in the paper and board industry. Resources, Conservation and Recycling, vol. 125, p. 218-232, D0l:10.1016/j.resconrec.2017.06.020.

[10] Saha, M., Eskicioglu, C., Marin, J. (2011). Microwave, ultrasonic and chemo-mechanical pretreatments for enhancing methane potential of pulp mill wastewater treatment sludge. Bioresource Technology, vol. 102, no. 17, p. 7815-7826, D0I:10.1016/j.biortech.2011.06.053.

[11] Bayr, S., Kaparaju, P., Rintala, J. (2013). Screening pretreatment methods to enhance thermophilic anaerobic digestion of pulp and paper mill wastewater treatment secondary sludge. Chemical Engineering Journal, vol. 223, p. 479-486, Dol:10.1016/j.cej.2013.02.119.

[12] Zhang, L., Xu, C.C., Champagne, P. (2010). Energy recovery from secondary pulp/paper-mill sludge and sewage 
sludge with supercritical water treatment. Bioresource Technology, vol. 101, no. 8, p. 2713-2721, D0l:10.1016/j. biortech.2009.11.106.

[13] Hay, J.X.W., Wu, T.Y., Juan, J.C., Jahim, J.M. (2015). Improved biohydrogen production and treatment of pulp and paper mill effluent through ultrasonication pretreatment of wastewater. Energy Conversion and Management, vol. 106, p. 576-583, DOI:10.1016/j.enconman.2015.08.040.

[14] de Azevedo, A.R., Alexandre, J., de C. Xavier, G., Pedroti, L.G. (2018). Recycling paper industry effluent sludge for use in mortars: A sustainability perspective. Journal of Cleaner Production, vol. 192, p. 335-346, D0l:10.1016/j. jclepro.2018.05.011.

[15] Singh, S., Kulkarni, S., Kumar, V., Vashistha, P. (2018). Sustainable utilization of deinking paper mill sludge for the manufacture of building bricks. Journal of Cleaner Production, vol. 204, p. 321-333, Dol:10.1016/j.jclepro.2018.09.028.

[16] Jaria, G., Calisto, V., Silva, C.P., Gil, M.V., Otero, M., Esteves, V.I. (2019). Obtaining granular activated carbon from paper mill sludge - A challenge for application in the removal of pharmaceuticals from wastewater. Science of The Total Environment, vol. 653, p. 393-400, Dol:10.1016/j. scitotenv.2018.10.346.

[17] Jin, Y., Li, H., Mahar, R.B., Wang, Z., Nie, Y. (2009). Combined alkaline and ultrasonic pretreatment of sludge before aerobic digestion. Journal of Environmental Sciences, vol. 21, no. 3, p. 279-284, D0I:10.1016/S1001-0742(08)62264-0.

[18] Patil, P.N., Gogate, P.R., Csoka, L., Dregelyi-Kiss, A., Horvath, M. (2016). Intensification of biogas production using pretreatment based on hydrodynamic cavitation. Ultrasonics Sonochemistry, vol. 30, p. 79-86, D0l:10.1016/j. ultsonch.2015.11.009.

[19] Carrère, H., Dumas, C., Battimelli, A., Batstone, D.J., Delgenès, J.P., Steyer, J.P., Ferrer, I. (2010). Pretreatment methods to improve sludge anaerobic degradability: A review. Journal of Hazardous Materials, vol. 183, no. 1, p. 1-15, D0l:10.1016/j. jhazmat.2010.06.129.

[20] Wang, X., Qiu, Z., Lu, S., Ying, W. (2010). Characteristics of organic, nitrogen and phosphorus species released from ultrasonic treatment of waste activated sludge. Journal of Hazardous Materials, vol. 176, no. 1, p. 35-40, D0l:10.1016/j. jhazmat.2009.10.115.

[21] Tyagi, V.K., Lo, S.-L., Rajpal, A. (2014). Chemically coupled microwave and ultrasonic pre-hydrolysis of pulp and paper mill waste-activated sludge: effect on sludge solubilisation and anaerobic digestion. Environmental Science and Pollution Research, vol. 21, no. 9, p. 6205-6217, D0l:10.1007/s11356013-2426-y.

[22] Oz, N.A., Uzun, A.C. (2015). Ultrasound pretreatment for enhanced biogas production from olive mill wastewater. Ultrasonics Sonochemistry, vol. 22, p. 565-672, D0I:10.1016/j.ultsonch.2014.04.018.

[23] Petkovšek, M., Mlakar, M., Levstek, M., Stražar, M., Širok, B., Dular, M. (2015). A novel rotation generator of hydrodynamic cavitation for waste-activated sludge disintegration. Ultrasonics Sonochemistry, vol. 26. p. 408414, D0I:10.1016/J.ultsonch.2015.01.006.
[24] Zupanc, M., Kosjek, T., Petkovšek, M., Dular, M., Kompare, B., Širok, B., Blažeka, Ž., Heath, E. (2013). Removal of pharmaceuticals from wastewater by biological processes, hydrodynamic cavitation and UV treatment. Ultrasonics Sonochemistry, vol. 20, no. 4, p. 1104-1112, D0l:10.1016/j. ultsonch.2012.12.003.

[25] Zupanc, M., Kosjek, T., Petkovšek., M., Dular, M., Kompare, B., Širok, B., Stražar, M., Heath, E. (2014). Shear-induced hydrodynamic cavitation as a tool for pharmaceutical micropollutants removal from urban wastewater, Ultrasonics Sonochemistry, vol. 21, no. 3, p. 1213-1221, D0l:10.1016/j. ultsonch.2013.10.025.

[26] Petkovšek, M., Zupanc, M., Dular, M., Kosjek, T., Heath, E., Kompare, B., Širok, B. (2013). Rotation generator of hydrodynamic cavitation for water treatment. Separation and Purification Technology, vol. 118, p. 415-423, D0l:10.1016/j. seppur.2013.07.029.

[27] Širok, B., Dular, M., Petkovšek, M., Zupanc, M. Heath, E. (2014). Rotation Generator of Hydrodynamic Cavitation for Water Treatement, SI24180 A, Slovenian Intellectual Property Office, Ljubljana. (in Slovene)

[28] Širok, B., Dular, M., Petkovšek, M. (2019). Cavitation Device for Treatment of Water by Cavitation. United States patent US10202288 B2, United States Patent and Trademark Office, Washington.

[29] Šarc, A., Oder, M., Dular, M. (2016). Can rapid pressure decrease induced by supercavitation efficiently eradicate Legionella pneumophila bacteria? Desalination and Water Treatment, vol. 57, no. 5, p. 2184-2194, D0l:10.1080/1944 3994.2014.979240.

[30] Šarc, A., Kosel, J., Stopar, D., Oder, M., Dular, M. (2018). Removal of bacteria Legionella pneumophila, Escherichia coli, and Bacillus subtilis by (super)cavitation. Ultrasonics Sonochemistry, vol. 42, p. 228-236, D0l:10.1016/j. ultsonch.2017.11.004.

[31] Dular, M., Griessler-Bulc, T., Gutierrez-Aguirre, I., Heath, E., Kosjek, T., Krivograd Klemenčič A., Oder, M., Petkovšek, M., Rački, N., Ravnikar, M., Šarc, A., Širok, B., Zupanc, M., Žitnik, M., Kompare, B. (2016). Use of hydrodynamic cavitation in (waste)water treatment. Ultrasonics Sonochemistry, vol. 29, p. 577-588, D0I:10.1016/j.ultsonch.2015.10.010.

[32] Šarc, A., Stepišnik-Perdih, T., Petkovšek, M., Dular, M. (2017). The issue of cavitation number value in studies of water treatment by hydrodynamic cavitation. Ultrasonics Sonochemistry, vol. 34, p. 51-59, D0l:10.1016/j. ultsonch.2016.05.020.

[33] Kosel, J., Gutiérrez-Aguirre, I., Rački, N., Dreo, T., Ravnikar, M., Dular, M. (2017). Efficient inactivation of MS-2 virus in water by hydrodynamic cavitation. Water Research, vol. 124, p. 465471, D0I:10.1016/j.watres.2017.07.077.

[34] Stepišnik Perdih, T., Širok, B., Dular, M. (2017). Influence of hydrodynamic cavitation on intensification of laundry aqueous detergent solution preparation. Strojniški vestnik Journal of Mechanical Engineering, vol. 63, no. 2, p. 83-91, DOI:10.5545/sv-jme.2016.3970.

[35] Zupanc, M., Pandur, Ž., Stepišnik Perdih, T., Stopar, D., Petkovšek, M., Dular, M. (2019). Effects of cavitation on different microorganisms: The current understanding of the 
mechanisms taking place behind the phenomenon. A review and proposals for further research. Ultrasonics Sonochemistry, vol. 57, p. 147-165, D0I:10.1016/j.ultsonch.2019.05.009.

[36] Kosel, J., Šinkovec, A., Dular, M. (2019). A novel rotation generator of hydrodynamic cavitation for the fibrillation of long conifer fibers in paper production. Ultrasonics Sonochemistry, vol. 59, ID 104721, Dol:10.1016/j.ultsonch.2019.104721.

[37] DIN 38409-2 (1980). German Standard Methods for the Examination of Water, Waste Water and Sludge; General Measures of Effects and Substances (Group H), Determination of the Total Nonfilterable Residue and Residue on Ignition (H2), German Institute for Standardisation, Berlin.

[38] ASTM E711-87 (2004). Standard Test Method for Gross Calorific Value of Refuse-Derived Fuel by the Bomb Calorimeter, ASTM International, D0I:10.1520/E0711-87r04.

[39] Stepišnik Perdih, T., Širok, B., Dular, M. (2017). On the bubblesurfactant interaction. Chemical Engineering and Processing: Process Intensification, vol. 121, p. 198-204, D0l:10.1016/j. cep.2017.08.016.

[40] Beare, M.H., Cabrera, M.L., Hendrix, P.F., Coleman, D.C. (1994). Aggregate-protected and unprotected organic matter pools in conventional- and no-tillage soils. Soil Science Society of America Journal, vol. 58, no. 3, p. 787-795, D0l:10.2136/ss saj1994.03615995005800030021x.

[41] Hart, P.W., Rudie, A.W. (2012). The Bleaching of Pulp, TAPPI press, Norcross.

[42] Irwin, W.J. (1995). Stability and characterization of protein and peptide drugs. case histories. Pharmaceutical Biotechnology vol. 5, Wang, Y.J., Pearlman, R. (eds.), Journal of Pharmacy and Pharmacology, vol. 47, p. 176, D0l:10.1111/j.2042-7158.1995. tb05773.x.

[43] Manning, M.C., Chou, D.K., Murphy, B.M., Payne, R.W., Katayama, D.S. (2010). Stability of protein pharmaceuticals: An update. Pharmaceutical Research, vol. 27, no. 4, p. 544575, DOl:10.1007/s11095-009-0045-6.

[44] Badve, M.P., Gogate, P.R., Pandit, A. B., Csoka, L. (2014). Hydrodynamic cavitation as a novel approach for delignification of wheat straw for paper manufacturing. Ultrasonics Sonochemistry, vol. 21, no. 1, p. 162-168, D0I:10.1016/j.ultsonch.2013.07.006.

[45] Das, A.B., Nagy, P., Abbott, H.F., Winterbourn, C.C., Kettle, A.J. (2010). Reactions of superoxide with the myoglobin tyrosyl radical. Free Radical Biology and Medicine, vol. 48, no. 11, p. 1540-1547, D0l:10.1016/j.freeradbiomed.2010.02.039.

[46] Golyshin, P.N., Martins Dos Santos, V.A.P., Kaiser, O., Ferrer, M., Sabirova, Y.S., Lünsdorf, H., Chernikova, T.N., Golyshina, O.V., Yakimov, M.M., Pühler, A., Timmis, K.N. (2003). Genome sequence completed of Alcanivorax borkumensis, a hydrocarbon-degrading bacterium that plays a global role in oil removal from marine system. Journal of Biotechnology, vol. 106, no. 2, p. 215-220, Dol:10.1016/j.jbiotec.2003.07.013.

[47] Aruga, S. Kamagata, Y., Kohno, T., Hanada, S., Nakamura, K., Kanagawa, T. (2002). Characterization of filamentous Eikelboom type $021 \mathrm{~N}$ bacteria and description of Thiothrix disciformis sp. nov. and Thiothrix flexilis sp. nov. International Journal of Systematic and Evolutionary Microbiology, vol. 52, no. 4, p. 1309-1316, D0l:10.1099/00207713-52-4-1309.

[48] Böhme, A., Risse-Buhl, U., Küsel, K. (2009). Protists with different feeding modes change biofilm morphology. FEMS Microbiology Ecology, vol. 69, no. 2, p. 158-169, Dol:10.1111/ j.1574-6941.2009.00710.x.

[49] Hahn, M.W., Höfle, M.G. (2001). Grazing of protozoa and its effect on populations of aquatic bacteria. FEMS Microbiology Ecology, vol. 35, no. 2, p. 113-121, D0l:10.1016/S01686496(00)00098-2.

[50] Weerman, E.J., Van Der Geest, H.G., Van Der Meulen, M.D., Manders, E.M.M., Van De Koppel, J., Herman, P.M.J. Admiraal, W. (2011). Ciliates as engineers of phototrophic biofilms. Freshwater Biology, vol. 56, no. 7, p. 1358-1369, D0I:10.1111/j.1365-2427.2011.02574.x.

[51] Eurostat (2109). Electricity Price Statistics, from https:// ec.europa.eu/eurostat/statistics-explained/index.php/ Electricity_price_statistics, accessed on 2019-09-10. 